\title{
Relationship Bystander Effect and Student's Prosocial Behavior at Faculty of Psychology, Medan Area University
}

\author{
Merri Hafni $^{1 *}$, Andy Chandra ${ }^{2}$, Siti Nurhalizah ${ }^{3}$ \\ ${ }^{1,2,3)}$ Faculty of Psychology, Universitas Medan Area, Indonesia \\ *hafnimerri@staff.uma.ac.id
}

\begin{abstract}
This study was conducted to determine the relationship between the by stanser effect with prosocial behavior in psychology students at the Medan Area University. Subjects in this study were 218 students of 2016 University of Medan Area Faculty of Psychology. The study employed purposive sampling technique. The data for bystander effect and prosocial behavior were collected by using two closed questionnaires. The results showed that there was a very significant and negative correlation between bystander effect with prosocial behavior $(r=0,786 ; p=0,000<0,05)$. Prosocial behavior in the psychology faculty at the University of Medan Area was classified as being shown a hypo thecal mean of $72.5>$ empirical mean of 59.49 where the difference between the two mean exceeds SD 13,029, the bystander effect was also classified as moderate because of hypothetical mean of 75> empirical mean of 63.49 where the second difference the mean exceeds the SD number 13,590. The coefficient of determination of the correlation $\mathrm{r} 2=0.610$ means that the bystander effect contributes effectively to prosocial behavior of $61.0 \%$ and from these results that there are still $38.2 \%$. Other factors that influence in this study that are not visible include attractiveness, attribution for victims, there is a model, time pressure, the nature of victim's needs, mood ,nature, gender, place of residence and parenting
\end{abstract}

Keywords: observer effect, early adulthood, students, prosocial behavior

\section{Introduction}

Humans are social creatures that live in society. Humans always live side by side with other humans, because humans cannot stand alone without help from other humans. In everyday life individuals help each other, such as helping others who are struggling on the road, so when other people see the incident, as social beings individuals should help people who are in need of help even though they do not know each other. Not only on the road, even in the neighborhood, individuals must be more caring and sensitive so that they can be well received by the community. One of the layers in society is early adulthood.

Early adulthood is included in the category of transition between adolescence to adulthood. According to Arnett [1] stated that the period of adolescence and adulthood is also called the preparation period (emerging adulthood) around the age of 18 to 25 years. Early adulthood is a period of seeking stability and a reproductive period that is a time full of problems and emotional dependence, a period of social isolation, a period of commitment and a period of dependence, changes in values, creativity and adjustment of a new lifestyle [2]. 
An individual who is said to be an adult can be seen from his social growth. Social growth is an understanding of how individuals love relationships, how individuals can understand their character and personality, not only that early adulthood must also have feelings of sympathy for others and even for someone or things that he likes the least [3]. Early adulthood enters adulthood where it is not only about physical maturity but is economically and psychologically independent, the point at which adolescents that enter adulthood are faced with choices such as whether to continue college or university or not [1]. Students include early adulthood, because a student is categorized at the stage of development whose age is 18 to 25 years.

The emergence of modernization and globalization now has a major impact on human life, resulting in a shift in the pattern of interaction between individuals with other individuals, and changes the values in social life. Interaction between individuals is reduced and social contact occurs have lower quality and quantity. One form of shifting patterns of relationships between individuals and other individuals in the surrounding environment is the depletion of prosaically behavior in society. Prosocial behavior according to Baron \& Byrne [4] is a voluntary behavior to help others without wanting to get rewarded and feel satisfied after helping.

Prosocial behavior has a special characteristic that puts the interests of others above personal interests. The welfare and benefit of a person or group is the goal of prosocial behavior. Eisenberg [4] said that prosocial behavior encompasses three aspects, namely, actions taken voluntarily, actions were taken are shown in the interests of others or groups of other people, those actions are goals not as tools to satisfy personal motives. Prosocial behavior is not only done by the community, but also by students. Because students are part of the community, not only that students must also be more active in the community or in their environment.

A student is someone who is in the process of gaining knowledge or studying and is registered while undergoing education at one of the colleges such as academics, polytechnics, high schools, institutes and universities [5]. Students as young intellectual candidates who are experiencing the learning process that is demanded by the community to have responsibilities in acting according to what is prevailing in the community such as mutual help, sharing, working together. But there are still many students who are less aware of the prosocial behavior importance in society. This is supported by a phenomenon that occurs at Medan Area University. The researcher notices a visually disabled man who is carrying his wares around the Medan Area University campus. The weather was drizzling, so the man wanted to find a shelter using his cane. Sadly no one helped him, but after a few minutes, there was someone who helped, unfortunately, it was not a student but an online motorcycle taxi driver, even though at that time there were many students around the bus stop. The students who were near the place were busy with their smartphones and there were even some who only gazing without any intention to help.

Prosocial behavior is one of the social relationships that must be carried out by students because prosocial behavior is a form of social relations that cannot be separated in people's lives. Students are young intellectual candidates who are experiencing a learning process that is demanded by the community to have responsibilities in acting according to the norms prevailing in the community such as helping one another, sharing, cooperating, but in reality a gap arises between people's expectations and the reality that happens to the lives of students, especially Psychology students.

The phenomenon of prosocial behavior that occurs in Psychology students is very alarming. Psychology students should have high sympathy and empathy for the people around 
them. This is because psychology students are expected to be able to establish good communication, be able to establish good relationships with others have good observations or be more sensitive to problems that occur in the social environment.

But in reality, psychology students are less sensitive, empathetic and sympathetic to their environment. This is shown in the results of interviews conducted by researchers with the Psychology student of University of Medan Area, class of 2016. The subject reveals that when seeing people who need help the subject does not immediately help, because the subject will see the situation first, if in the vicinity are crowded and he/she was in a rushed situation, the subject will not immediately help, the subject thinks there must be someone who will help. Common reasons for not coming to help the victim include fearing that the risk of personal danger is too great and feeling that he/she does not have the strength or other qualities needed to help with the assumption that others are more qualified than he/she is and consider the situation not as serious as the subject previously thought because those around or those present in the accident did not look worried for fear of being targeted by aggression or intimidation.

Based on the interviews it can be concluded that the lack of prosocial behavior can occur or be caused by several factors. Factors that influence prosocial behavior can be categorized into two, namely situational factors and internal factors. Situational factors include bystander, attractiveness, attribution to victims, models, insistence on time, and nature of victims' needs. Whereas internal factors are mood, nature, gender, place of residence and parenting [6]. Prosocial Behavior used by researchers is stated by Mussen \& et al [7], revealing that aspects of Prosocial Behavior include: helping, namely helping others by alleviating the physical or psychological burden of the person, sharing feelings or empathy, that is a willingness to share what is felt perceived by others, cooperation, that is, doing work or activities together based on agreement to achieve a common goal, and contributing, that is being generous to others. Paying attention to the welfare of others, namely caring for other people's problems. Researchers focus on the bystander effect where bystander or the presence of other people has the perception that other people act to help, hence he/she did nothing to help. If in an emergency the individual response are faster when he/she is alone than if they have the assumption that other people also know the situation [8]. When the situation at the scene is filled with many people, the behavior of help tends to be smaller.

This is supported by the bystander effect theory which stated that a person's likelihood of helping will be smaller when the person is with someone else. The more people there are, the less likely it is to help. Widyastuti [8] stated that the factors that influence bystander are:

a. Spread of responsibility

The distribution of responsibilities arising from the presence of another person, if only one person witnesses a victim who is experiencing difficulties then that person has full responsibility to react to the situation and will bear guilt and regret if they do not act.

b. Ambiguity effect

Helpers are sometimes unsure whether certain situations are truly emergency situations. Sometimes the calm of others is also present causing the subject to interpret the situation as a harmless situation.

c. Fear to be assessed

When we know that other people are paying attention to our behavior, maybe we will try to do what is expected by others and make a good impression.

d. Environmental conditions

Physical condition also affects the willingness to help. A common stereotype is that city people are unfriendly and do not like to help compared to villagers who are friendly and strong in a culture of help. Noise also influences helpful behavior because loud noise 
causes people to ignore others around them and motivate them to leave the situation immediately.

e. Time pressure

Rationality (common sense) and research show evidence that sometimes we are in a hurry to help so we decide not to take action.

According to Davidson [9] aspects of the bystander effect are the potential to intervene, prevent violence, opportunities to provide assistance. The above case is supported by research conducted by Darley and Latane [10] who designed a study in which students who heard of an emergency were more likely to react when they were alone, if they had the notion that others also knew the situation, the more people present, the less likely someone is to really help. Prosocial behavior is influenced by good situational bystander, prestige, and fear of being judged by others and throwing responsibilities.

Researchers consider this research important because prosocial behavior in students is slightly decreased due to several factors that influence prosocial behavior, including bystander effect. Therefore the researchers took the title "The Relationship between the Bystander Effect with Prosocial Behavior in Psychology Students of the Medan Area University"

\section{Research Method}

The sample in this study was the Psychology Students of the University of Medan Area, class of 2016, consisting of class A, B, C and D as many as 218 students. Sampling in this study used total sampling, which is a sampling technique where the number of samples is equal to the population [10]. Thus the number of samples in the study is known to be 218 students.

The instrument in this study consisted of two, namely the intensive scale of social media intensity usage and the scale of social interaction. On the scale of the bystander effect is arranged based on aspects stated by Davidson [9] namely the potential to intervene, prevent violence, the opportunity to assist. This scale is also arranged based on a Likert scale with 4 answer choices, namely Very Appropriate (SS), Appropriate (S), Unsuitable (TS) and Very Unsuitable (STS). On the scale of Prosocial Behavior is arranged based on aspects stated by Mussen et al. [7] namely: helping, sharing feelings or empathy, cooperation, donating, paying attention to the welfare of others. This scale is also arranged based on a Likert scale with 4 answer choices, namely Very Appropriate (SS), Appropriate (S), Unsuitable (TS) and Very Unsuitable (STS).

The bystander effect is a person who is in a situation only chooses to be an observer, witnesses the danger that occurs, but does nothing to help or stop the incident. Prosocial behavior is a voluntary action intended to help or benefit a group of others or a group of individuals.

\section{Results and Discussion}

The normality test results show that the bystander effect variable data and prosocial behavior have normal distribution of data, which is indicated by the Kolmogorov-Smirnov coefficient. With $\mathrm{p}>0.05$ the distribution is normal, otherwise if $\mathrm{p}<0.05$ the distribution is declared abnormal. The linearity results show that the bystander effect variable is linearly related to prosocial behavior, which is indicated by the linearity coefficient $F=0.781$, as a criterion if $\mathrm{p}<0.05$. 
Simple regression analysis results can be concluded that there is a significant relationship between the bystander effects with prosocial behavior in students of the Faculty of Psychology, University of Medan Area. It evidenced by the correlation coefficient $r_{x y}=0.781$ with $\mathrm{p}<0.05$, meaning that based on the results of this study, it can be stated that there is a positive relationship between the bystander effect and prosocial behavior in the students of the Faculty of Psychology, University of Medan Area, class of 2016 with the results of more bystander resulted in the higher of the prosocial behavior, conversely the less bystander the lower the prosocial behavior. Based on these results, the hypothesis proposed in this study was declared rejected. Because the hypothesis proposed by researchers is that the more bystander, the lower the prosocial behavior, conversely the less bystander, the higher the prosocial behavior.

Based on these results, the bystander effect has a high impact on prosocial behavior on the students of the Faculty of Psychology, University of Medan Area. Based on this study it is identified that the bystander effect contributes $61 \%$ to prosocial behavior in students of the Faculty of Psychology, University of Medan Area. Other factors that influence in this study that are not visible include attractiveness, attribution to the victim, there is a model, time pressure, the nature of the victim's needs, mood, nature, gender, place of residence and parenting.

Table 1. Results for Product Moment Correlation

\begin{tabular}{|c|c|c|c|c|c|}
\hline Statistics & Coefficient $\left(r_{x y}\right)$ & Coef.Det. $\left(\mathrm{r}_{2}\right)$ & $\mathrm{P}$ & $\mathrm{BE} \%$ & Des. \\
\hline $\mathrm{X}-\mathrm{Y}$ & 0,781 & 0,610 & 0.000 & $61,0 \%$ & Significance \\
\hline \multicolumn{6}{|l|}{ Description: } \\
\hline $\mathrm{X}$ & \multicolumn{5}{|l|}{$=$ Bystander effect } \\
\hline Y & \multicolumn{5}{|c|}{$=$ Prosocial Behavior } \\
\hline rxy & \multicolumn{5}{|c|}{$=$ The coefficient of relationship between $\mathrm{X}$ and $\mathrm{Y}$} \\
\hline $\mathrm{r} 2$ & \multicolumn{5}{|c|}{$=$ The determinant coefficient of $\mathrm{X}$ to $\mathrm{Y}$} \\
\hline $\mathrm{p}$ & \multicolumn{5}{|c|}{$=$ Chance of error } \\
\hline $\mathrm{BE} \%$ & \multicolumn{5}{|c|}{$=$ The weight of effective contribution of $\mathrm{X}$ to $\mathrm{Y}$ in percent } \\
\hline Des & \multicolumn{5}{|l|}{$=$ Significance } \\
\hline
\end{tabular}

\section{Conclusion}

Based on the results obtained in this study, the following conclusions can be presented: There is a positive relationship between the bystander effect with prosocial behavior in psychology students where $r_{x y}=0.781$ with a significant $p=0.000<0.050$. This means that the hypothesis proposed; the more observers (bystander), the lower the prosocial behavior, and vice versa the fewer observers (bystander), the higher the prosocial behavior is declared "rejected". This was rejected because of the results of this study; the more bystanders, the higher the prosocial behavior, conversely, the fewer bystanders, the lower the prosocial behavior.

The results of the validity and reliability test of the measuring instrument are known bystander effect scale of 34 items, there are 5 items that fall which are numbers $2,8,9,10,17$. 
And 29 other items are valid having a Corrected Total Item Correlation score $\left(\mathrm{r}_{\mathrm{xy}}\right.$ difference power index $\geq 0.3$; with a moving score from reliability $=0.353$ to reliability $=0.717$ with a Cronbach Alfa reliability score of 0.930 which means the bystander effect scale is relatively reliable. While the prosocial behavior of 36 items 7 items fall namely number 2, 8, 13, 14, 17, 18,36 . And 29 other valid items have a Corrected Total Item Correlation score $\left(\mathrm{r}_{\mathrm{xy}}\right.$ difference power index $) \geq 0.3$; with a moving score from reliability $=0.300$ to reliability $=0.687$ with a Cronbach Alfa reliability score of 0.918 which means prosocial behavior is classified as reliable.

The determinant coefficient (r2) of the relationship between the independent variable $(\mathrm{X})$ with the dependent variable $(\mathrm{Y})$ is equal to 0.610 . This indicated that the bystander effect contributes to prosocial behavior. Contribution from the bystander effect variable was $61 \%$ means that in this case there are 39\%. Other influencing factors in this study that were not seen include attractiveness, attribution to victims, models, insistence on time, nature of victims' needs, moods, traits, gender, place of residence and parenting.

Based on the results of this study, it is also identified that the bystander effect is generally classified as moderate and social behavior is generally stated to be moderate. This is based on an empirical average value of 63.49 smaller than the average hypothetical value (75), while for prosocial behavior variables is 59.55 smaller than the hypothetical mean value (72.5).

\section{References}

[1] Upton.P. (2012), Psikologi Perkembangan.Jakarta : Erlangga.

[2] Hurlock, B.E. (1980), Psikologi Perkembangan Suatu Pendekatan Sepanjang Rentang Kehidupan. Jakarta; Erlangga.

[3] Jahja,Y. (2011), Psikologi Perkembangan. Jakarta :Prenada Media Group.

[4] Muryadi \& Matulessy, A. (2012), Religiusitas, Kecerdasan Emosi dan Perilaku Prososial Guru. Jurnal Psikologi, 7(2).

[5] Hartaji, D. A. (2012), Motivasi Berprestasi Pada Mahasiswa Yang Berkuliah Dengan Jurusan Pilihan Orang Tua. Fakultas Psikologi Universitas Gunadarma.

[6] Sarwono,W. S. \& Meinarno, A.E. (2009), Psikologi Sosial. Jakarta: Salemba Humanika.

[7] Nashori, F. H. (2008), Psikologi Sosial Islam. Bandung: PT. Refika Aditama.

[8] Widyastuti.Y. (2014), Psikologi Sosial. Yogyakarta : Graha Ilmu.

[9] Davidson, M. C. (2012), Predictor Of College Women's Prosocial Bystander Intervention: PersonalCharacteristics, Sexual Assault History And Situational Barriers. Thesis.

[10] Sears,O. D,Freedman, J. L. (1985), Psikologi Sosial (5 ${ }^{\text {th }}-$ Ed), Jakarta :Erlangga.

[11] Sugiyono. (2009), Statistik Untuk Penelitian. Bandung :Alfabeta. 